Natural Hazards and Earth System Sciences (2005) 5: 225-233

SRef-ID: 1684-9981/nhess/2005-5-225

European Geosciences Union

(C) 2005 Author(s). This work is licensed

under a Creative Commons License.

\title{
A review of the potential and actual sources of pollution to groundwater in selected karst areas in Slovenia
}

\author{
G. Kovačič ${ }^{1}$ and N. Ravbar ${ }^{2}$ \\ ${ }^{1}$ University of Primorska, Faculty of Humanities Koper, Department of Geography, Glagoljaška 8, SI-6000 Koper, Slovenia \\ ${ }^{2}$ Karst Research Institute, SRC SASA, Titov trg 2, SI-6230 Postojna, Slovenia
}

Received: 7 July 2004 - Revised: 16 November 2004 - Accepted: 8 February 2005 - Published: 17 February 2005

Part of Special Issue "Natural and anthropogenic hazards in karst areas"

\begin{abstract}
Slovenian karst areas extend over $43 \%$ of the country; limestones and dolomites of the Mesozoic era prevail. In Slovenia karst groundwater contributes up to $50 \%$ of the total drinking water supply. The quality of water is very high, despite the fact that it is extremely vulnerable to pollution. The present article is a study and a review of the potential and actual sources of pollution to the groundwater in the selected karst aquifers (the Kras, Velika planina and Snežnik plateaus), which differ in their natural characteristics. Unlike the other selected plateaus, the Kras plateau is inhabited. There are several settlements in the area and the industrial, agricultural and traffic activities carried out that represent a serious threat to the quality of karst groundwater. The Velika planina and Snežnik plateaus do not have permanent residents, however there are some serious hazards to the quality of the karst springs arising from sports, tourist, construction and farming activities, as well as from the traffic related to them. Despite relatively favourable conditions for protection, many important karst aquifers and springs are improperly protected in Slovenia. The reason is the lack of knowledge about sustainable water management in karst regions and the confusion in drinking water protection policy.
\end{abstract}

\section{Introduction}

In Slovenia karst regions extend over $43 \%$ of the country, spreading from the Karavanke range and the plateaus of the Julian and Kamniške-Savinjske Alps at an altitude of $2500 \mathrm{~m}$ to the shore of the Mediterranean Sea. Tectonically, karst regions mainly belong to the Dinarids; limestones and dolomites of the Mesozoic era prevail. In Slovenia karst groundwater is extensively used for drinking water supply

Correspondence to: N. Ravbar

(natasa.ravbar@zrc-sazu.si) and it supplies around half of the country's needs. In general, the quality of karst groundwater is satisfactory, although it is extremely vulnerable to pollution. According to their intrinsic characteristics, not all of the karst regions are sensitive to groundwater pollution equally. Despite relatively favourable conditions for water protection (scarce population, less intensive agricultural activities, etc.) compared with regions, where potable water is pumped up from the granular aquifers, many important karst springs in Slovenia are, due to insufficient groundwater protection policy, improperly protected.

The present article is a study and a general review of the potential and actual hazards to the groundwater in the selected karst aquifers, which differ in regional range, hydrological characteristics and types of karst. Thus we present an aquifer of the Alpine karst (the Velika planina plateau), an aquifer of the High Dinaric karst (the Snežnik plateau) and an aquifer of the Low Dinaric karst (the Kras plateau). For locations see Fig. 1.

In the context of groundwater contamination, a hazard is defined as an existing and potential source of contamination resulting from human activities taking place mainly at the land surface (Zwahlen, 2004). Hazard classification in the present article is based on type of human activities placed in the background of associated karst resources and sources. The main issue of this paper is not a complex study and the precise classification and characterization of hazards in the selected karst aquifers, but more a qualitative description of the most serious potential and actual polluters. The goal of the paper is to present the distinction and to discuss the different form of possible and actual anthropogenic impact to groundwater quality in chosen three karst aquifers, showing the locations and the types of hazards coming from different human activities.

One of the major criteria for selecting these aquifers is also the availability and quality of the data of bacterial and chem- 


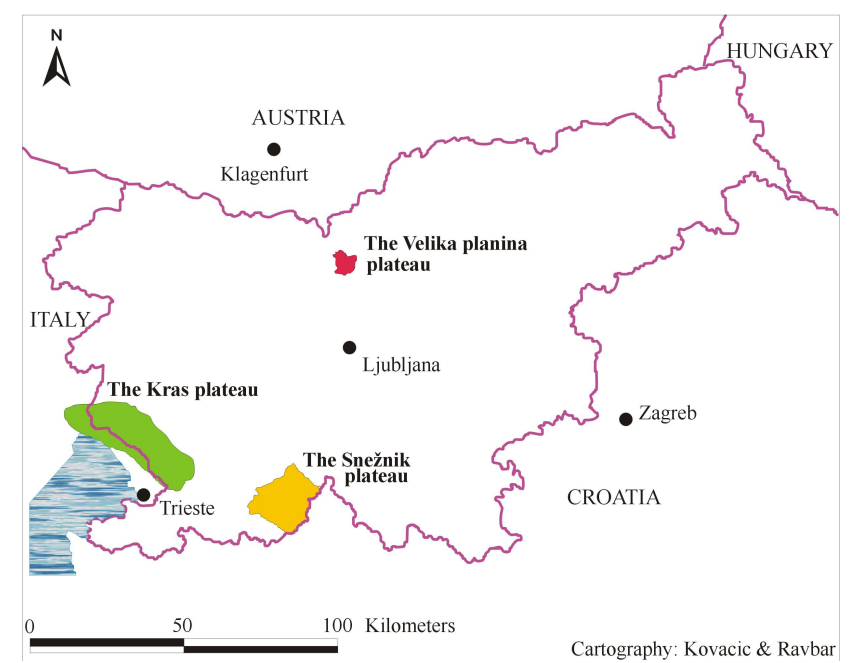

Fig. 1. Geographical position of the selected karst aquifers in Slovenia.

ical characteristics of some springs, effluents and of groundwater sensitivity gathered by previous investigations (Novak, 1994/1995; Kogovšek, 1996; Poročila o preskusu pitne vode za zajetje Bistrica, 1999-2003 ${ }^{1}$ ).

Geographical position, geological and hydrogeological characteristics of the selected aquifers are explained in the text and also shown on the simplified maps. In the case of the Velika planina and Snežnik karst plateaus the actual and the potential polluters are additionally illustrated on the same maps. Because of the variety and density of occurrence, the locations of potential and actual polluters of groundwater on the Kras plateau are shown on additional map.

\subsection{Karst groundwater protection in Slovenia}

Basic legislative provisions concerning groundwater protection policy in Slovenia and consequently the protection of karst aquifers are part of the new Waters Act, proclaimed in July 2002. Pursuant to articles 74 to 76 of the Act, the government and its institutions are responsible to establish water protection areas and regimes and to ensure the implementation of the provisions in each protection zone (Waters Act, 2002). The elaboration of the scientific basis for the determination of water protection zones and protection of springs and wells is in the hand of different public institutions and also accredited private institutions. Since the new Waters Act has been in force for only a relatively short period, regulation acts for standardizing the methodology and rules for defining the water protection zones of groundwater resources intended for human consumption are still in preparation and have not yet been adopted.

According to the old Waters Act (1981) and its amendments, the delineation of water protection zones fell within

${ }^{1}$ Water quality monitoring reports of the Bistrica spring capture, Health protection institute of the Republic of Slovenia, Koper, 1999-2003. the responsibility of local communities. Consequently, adequate protection of many important karst aquifers was and still is hindered by administrative borders between these communities. There was no legal basis set up in the above mentioned act for establishing a uniform methodology for the determination of water protection areas, which led to confusion and consequently resulted in non-comparable water protection areas and regimes for different water resources. In practice three different methodologies were used (Prestor, 2002). Their common characteristics are the transfer time of a contaminant from the point of injection to the target (spring or a well), which defines different water protection zones and the division of the hydrogeological background of drinking water resources into three basic protection zones. In some cases also the fourth zone is added that coincides to the possible influence area of the related water resource.

In most cases groundwater protection zones in Slovene karst regions are often not established on a solid hydrogeological basis, meaning that the different protection zones are in most cases delineated on the basis of available information on geological structure, though tracer tests or measurements of water table in wells are needed for the adequate validation of assessed extents of individual protections zones. Increasing conflicts between land use and demands for water protection often lead to a situation where there are no water protection areas and regulations established. It must be stressed that even in cases where water protection zones and regimes are established the implementation of regulations is frequently not effective. Thus many important karst springs tapped for water supply are still not properly protected.

\section{The Kras plateau}

\subsection{Natural characteristics}

The Kras plateau covers about $440 \mathrm{~km}^{2}$. It extends mainly in the Dinaric northwest-southeast direction and inclines upward from northwest to southeast. It lies between the Gulf of Trieste to the west and southwest, the alluvial Soča valley to the north, and the flysch Vipava valley to the northeast. In the east it borders on the Pivka basin and toward the southeast on the Brkini hills and the valley of the Reka river. Only towards south its border is less distinct. The Kras plateau reaches heights from 200 to $600 \mathrm{~m}$ above the sea level (Kranjc et al., 1999).

It is composed primarily of Mesozoic and Tertiary carbonate rock. These are mostly limestone and dolomite of the Cretaceous and Paleocene age (Kranjc et al., 1999). The most karstified are heavily fractured and well permeable Cretaceous limestones. To the north along the Vipava valley, the carbonate rock of the Cretaceous age changes into less permeable layers of Tertiary sandstone, plate limestone and flysch, and to the south and southwest, through Paleocene limestone into Eocene flysch. Paleocene layers of a more resistant limestone also compose the highest elevations on the 


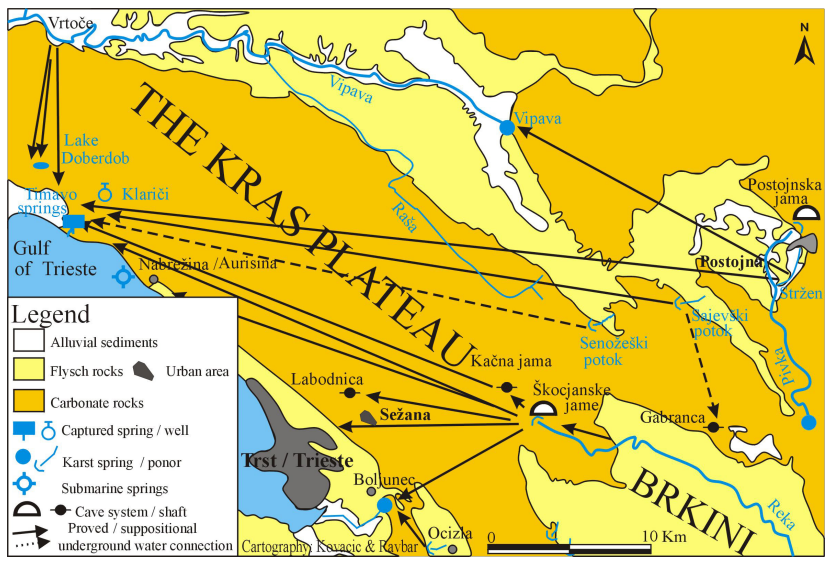

Fig. 2. Simplified geological map of the Kras plateau with proved and supposed groundwater connections (based on: Buser et al., 1963; Buser, 1964; Pleničar et al., 1965, source: Timeus, 1928; Gemiti, 1984; Cività et al., 1995).

northern border of the plateau (Buser, 1973; Jurkovšek et al., 1996).

In the studied area the cave density is among the highest in Slovenia and reaches from 1.5 up to 2.4 caves per $\mathrm{km}^{2}$. According to the Cadastre of Caves $(2003)^{2}, 626$ caves, among which shafts prevail, were registered in the studied area. Average length of the caves is $83 \mathrm{~m}$, but only 8 of them are longer than $500 \mathrm{~m}$. Average depth of the caves is $30 \mathrm{~m}$, but only 5 of them are deeper than $200 \mathrm{~m}$. Registered caves are evenly distributed over the plateau. The Škocjanske jame caves are the biggest cave system in the area with passages in a total length of $5.8 \mathrm{~km}$. They are also included in UNESCO's list of World Natural and Cultural Heritage sites. In spite of very big density of caves in this area the majority of underground water channels is, unfortunately, not accessible. Permanent or periodical water flow can be reached only in 7 caves. Therefore information on underground water circulation is very limited.

There are no waters running on the surface of the Kras limestone plateau. The aquifer of the Kras plateau is fed by the autochthonous precipitation waters and from the sinking rivers at its border (Reka, Sajevški potok, Senožeški potok and streams from Brkini hills) (Krivic et al., 1989). On the northwestern part the Kras aquifer is also fed by underground infiltration from the intergranular aquifer of the Vipava and Soča rivers. The Kras aquifer empties in numerous small surface and submarine karst springs on the western and northwestern edge (see Fig. 2). On the basis of these data we can deduce that the groundwater level is inclined from southeast to northwest and from the east to west (Habič, 1984).

The aquifer of the Kras plateau is an important source of drinking water in southwestern Slovenia, but the advantages of its capacities are not yet fully taken (Krivic, 1983). Water

\footnotetext{
${ }^{2}$ Cadastre of caves, Speleological association of Slovenia and Karst research institute SRC SASA, Ljubljana, 2003.
}

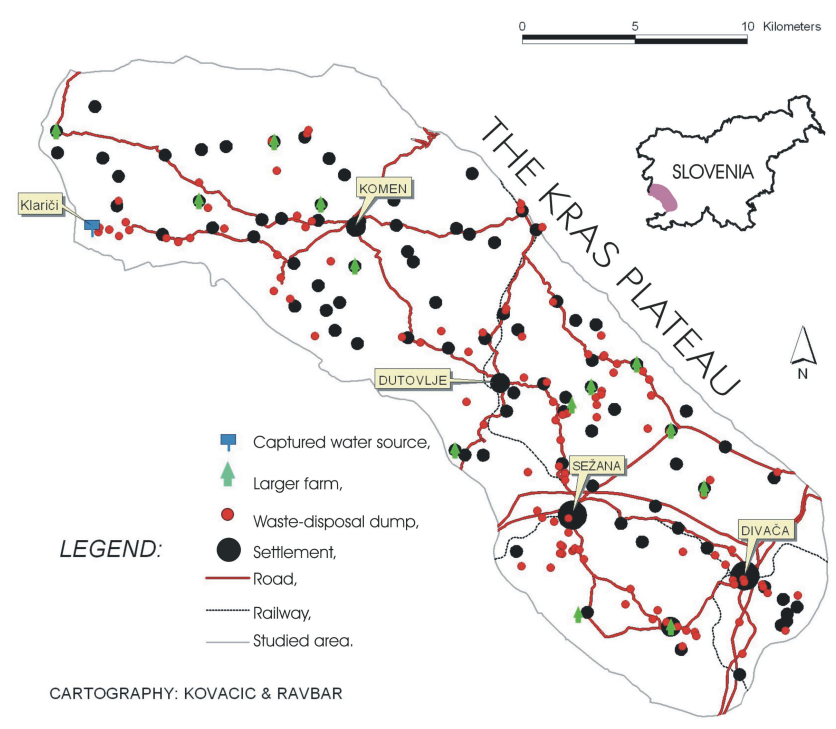

Fig. 3. Simplified hazard map of the Kras plateau.

supply is founded on the effective karst groundwater pumping near Klariči.

\subsection{Description of hazards}

The Kras plateau is relatively disperse and scarcely inhabited - the density of population is 44 inhabitants per $\mathrm{km}^{2}$. There are clumpy little villages with up to 200 inhabitants and five settlements with more than 500 inhabitants. The largest settlement is Sežana (4800 inhabitants), which is also the administrative and cultural centre. It is also a seat of the industrial (food, textile, chemical and construction industry) activities. Divača (1300 inhabitants) is an important railway junction.

Sources of pollution of karst groundwater result from settlements mainly because of sewage from households, polluted waters from roads and traffic, industrial polluted wastewaters, from illegal dumps and other. Direct outflow of the discharge waters into the karst aquifer without preliminary cleaning slowly but persistently poisons stock of karst groundwater. The most serious potential and actual hazards of groundwater in the Kras aquifer are briefly described below and also shown on the Fig. 3. The diffuse sources of pollution, for instance more intensive agriculture areas with high demand of fertilizers and protective means as vineyards, are due to the legibility of the map not illustrated.

In the settlements of the studied area sewage systems are very limited. All settlements on the plateau except Sežana, Divača and Senožeče still do not have regulated sewerage and treatment of sewage. Wastewaters from households in other settlements are drawn off to cesspits and there is only a small portion of such which have impermeable bottoms.

Landfill of waste materials in Sežana is intended for disposal of waste materials from households and of special waste materials from industry, and of craft and other activities under conditions which are paraphrased by the Rules 
on the management of waste of 1998. The landfill of waste materials in Sežana has legally regulated status, but it does not entirely meet the demands of the new Slovene legislation (Decree on the emission of substances in the discharge of landfill effluent, 2000) and European guidelines. The existing dump is already old and urgently needs rebuilding and widening. An enlargement of the dump place to the west and to the northwest for additional 5 ha is foreseen. Analyses of discharge waters from the Sežana dump have shown high organic pollution (Kogovšek, 1996). COD and BOD 5 have exceeded the limit value. Evaluations of the tracing tests have shown that discharge waters from the Sežana dump can reach sources of the Timavo river within three to twelve days.

There have been 59 illegal dumps registered on the surface of Kras and another 55 of them in the caves. Illegal garbage dumps derive from times when collection of waste was not organized. Many of them are, unfortunately, still in use today. Among waste material building and excavation material, rural and furniture waste material prevail. There are also dangerous materials. In spite of restrictions and interdiction of definite activities on the protected area we found that in the second water protection zone of the Klariči water source there is an abandoned illegal dump of building material. In the third water protection zone, where spreading of certain activities is strictly forbidden, we identified 12 more illegal dumps that mostly consisted of rural, building and also of dangerous waste materials.

The Kras plateau lies on the crossroads of important routes, which connect the Po lowland, respectively, Northern Adriatic Sea with the Panonian basin and connections also link the Northern Mediterranean and the Central Europe. Average daily traffic on highways crossing the plateau reached 12812 vehicles in 2001. On the Kras only highway sections and a main road in Sežana have regulated roadside channels, where meteoric waters are collected and drained off. From the other roadways dirt is washed directly underground. Therefore transport of dangerous material signifies special danger in freight traffic. Especially the consequences of accidents could cause uncontrolled leakage of this material into environment. Although transport of dangerous material by railway is safer than transport by road, the bigger part of transportation is still based on road transport. Slovenian Railways estimate that over 9 million tons of goods have been carried over border crossings Fernetiči and Vrtojba and from/to the Port of Koper in 2002. 6\% of it was chemical products and $9 \%$ petroleum and derivatives. The most dangerous materials have been carried over the section Ljubljana - Koper that crosses Kras.

Agriculture is no longer an important activity and is restricted to cultivation of small fields on the bottom of depressions on the plateau. Production is therefore directed to selfsufficiency. Viticulture is coming to the fore and is becoming the most profitable rural activity in the past few years. Intensely cultivated vineyards and orchards, where a lot of fertilizers and protective means are used, are the areas most exposed to suspended pollution. Because the quantity and quality of the crops depend completely on use of the phyto- pharmaceutical products in intensive viticulture, for achieving bigger yields winegrowers usually use too much of these preparations (Rejec-Brancelj, 2001).

On the Kras plateau constant sources of pollution are also disorderly-manured dung heaps, cesspits and stocks of stable manure, from where discharge waters drain into the underground. Diffuse sources of pollution are immoderate fertilizing of fodder plants, above all with mineral fertilizers, use of other agrochemical means for protection of plants and uncontrolled fertilizing with manure during the wrong time of the year.

The stud farm and tourist recreative center Lipica is known as the biggest polluter of the karst groundwater. It pollutes underground water with disorderly discharges of dirty water from the stables and with sewage. Wastewaters are drawn off to obsolete water treatment plant with mechanical treatment, and then directly into nature. The analyses of the outflow showed that this source of pollution immoderately contaminates the environment. Measured values of COD, $\mathrm{BOD}_{5}$, total phosphorus, suspended solids, nitrites and total tenzides surpass the maximum permissible values according to the Decree on the emission of substances in wastewater discharged from urban waste water treatment plants (1996).

Industrial production on the Kras plateau is limited and concentrated above all in bigger urban areas. Among industries the biggest pollutant of karst waters is the ham-curing plant Kras in Šepulje, the leading meat processing industry in Slovenia. The collection and drainage system of its wastewater is not built. The analyses of discharge waters have shown, that they contain too big toxicity for water fleas and too high values of oil and grease, total phosphorus, chloride, $\mathrm{AO}_{\mathrm{x}}$, $\mathrm{COD}$ and $\mathrm{BOD}_{5}{ }^{3}$.

Mitol, the glue factory, is also one of the biggest potential polluters of karst groundwater because of possibility of pouring out of chemical substances. They store 250-300 tons of dangerous material, which is kept in entrenched reservoirs. Their technological sewage is at first drawn off to their own water treatment plant and then to the public water treatment plant, where they do not exceed values stipulated by the Decree on the emission of substances in waste water discharged from urban waste water treatment plants (1996).

Tourist potential on the Kras is extraordinarily high, however its offer and service is very moderate. The area has big possibilities for the development of different ways of tourism, because it lies in the hinterland of important coastal towns. In order to reduce the potential pollution of karst groundwater to minimum, reasonable regulation of dispersed tourist centers is necessary. It would be necessary to consider carefully, what degree of tourist visiting Kras can accept in sense of increased consumption of drinking water and the consequent enlarged amounts of wastewaters.

\footnotetext{
${ }^{3}$ Report on discharge water sampling and field measurements, Ham-curing plant Šepulje, Health protection institute of the Republic of Slovenia, Koper, 10, 2001.
} 


\section{The Velika planina plateau}

\subsection{Natural characteristics}

Velika planina is found on the eastern part of the KamniškeSavinjske Alps massif. It is a high alpine karst plateau at the altitude between 1300 to $1600 \mathrm{~m}$. It is mainly inclined towards the east. The studied area, which forms a geographical unit named Velika planina, encompasses three mountain meadows with the associated pastures (Velika, Mala and Gojška planina).

The relatively recognizable bordered karst aquifer is surrounded by the valley of Kamniška Bela on the northwest, Kamniška Bistrica on the west, črna on the south, Volovjek on the southeast, the valley of Brložnica with the spring of Lučnica on the east and the valley of Lučka Bela on the northeast (see Fig. 4). On the northern side Velika planina is connected with the eastern side of the Kamniške-Savinjske Alps across the mountain Rzenik (1833 m). Excluding the eastern side of the plateau, slopes on all margins are rather steep.

In the geotectonic sense the studied area belongs to the Southern Alps. Velika planina is a big shallow syncline of the Savinja thrust sheet, composed mainly of Middle and Upper Triassic carbonates and pushed southward on Tertiary layers of the Tuhinj syncline. It is bordered by faults on all sides (Premru, 1982). Along the northern edge of the syncline anizic clastites, marl and breccia appear.

Several expressive dish-shaped or funnel-shaped dolines, collapse dolines and dry valleys are to be found on the Velika planina plateau. Also other characteristic karst features appear on the plateau, such as snow kettles, solution pans and karren. According to the data of Cadastre of caves (2003) ${ }^{4}$ there have been 16 caves registered in the studied area. Average length of these caves is $120 \mathrm{~m}$, however more than $80 \%$ of them are shorter than $100 \mathrm{~m}$. Average depth of the caves is $26 \mathrm{~m}$ among which more than one half does not extend more than $10 \mathrm{~m}$ in depth. The longest and the deepest cave is Jama $\mathrm{v}$ Kofcah that is $1090 \mathrm{~m}$ long and $103 \mathrm{~m}$ deep.

At the edge of Velika planina some more sufficient springs can be found. Tracings have shown that waters mostly outflow toward the Lučnica spring (see Fig. 4). Numerous sources that are on the margins of the plateau supply smaller areas with drinking water. Also numerous small springs on the plateau are captured for the local water supply of nearby lodging houses.

\subsection{Description of hazards}

The Velika planina plateau does not have permanent residents. There are around 170 holiday huts, some mountain lodging houses and some pastoral houses still used by herdsmen. Settlements of holiday huts are restricted to the northwestern part of the plateau (around Šimnovec), where it is not so convenient for pasturing. The most important economic

\footnotetext{
${ }^{4}$ Cadastre of caves, Speleological association of Slovenia and Karst research institute SRC SASA, Ljubljana, 2003.
}

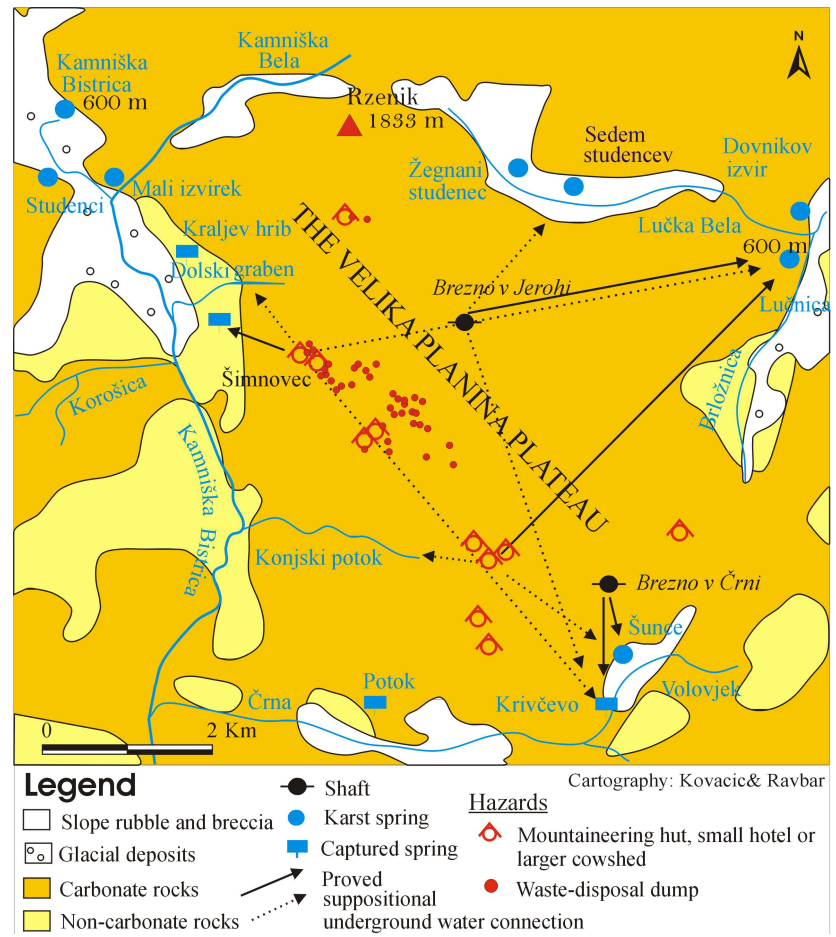

Fig. 4. Simplified geological and hazard map of the Velika planina plateau with proved and supposed underground water connections (based on: Novak, 1994/1995).

branch in the warm season is stockbreeding, but above all tourism occurs all the year round. However, on all mountain pastures of the Velika planina plateau pasturing is strongly connected to tourism and most of the pastoral houses have been changed into mountain lodging houses.

In the second half of the $20^{\text {th }}$ Century more mountain huts and a cableway with load capacity 400 people/h and some chair lifts were built. There are many trails, footpaths and lately more and more tractor roads have appeared. With new infrastructure tourist development accelerated. There are 244 beds registered altogether, but the actual number of beds is even bigger while there is a possibility of cottage rental.

The one-day guests mostly visit Velika planina, only during the summer and winter months also stationary tourism is present. In 2001 almost 40000 people were carried by the cableway (one forth of the total in August), at least double this number come to the mountain on foot. Of the illusory plans to modify the Velika planina plateau into a ski center in the 1970s only the construction of ski lifts have been realized. Today there are about $40 \mathrm{ha}$ of ski slopes and $7 \mathrm{~km}$ of ski routes (Kopač, 1991).

On the Velika planina plateau point hazards prevail. Danger to the underground water comes above all from percolated waters from cesspits. Holiday settlements, mountain lodging houses and pastoral houses do not have suitable systems for the wastewater drainage. Only the biggest mountain hut regularly sends away wastewaters to the central water treatment plant. Faecal waters flow into permeable cesspits 


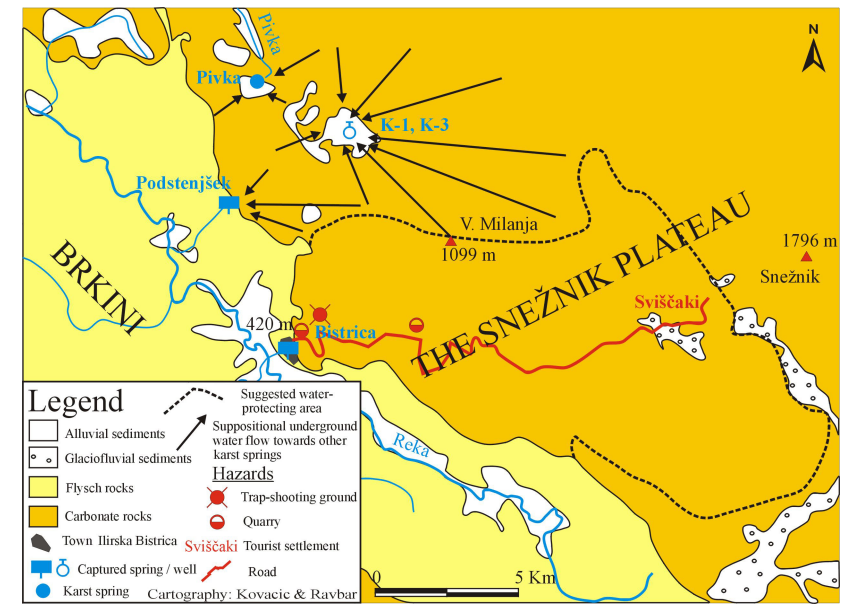

Fig. 5. Simplified geological and hazard map of the Snežnik plateau with the extent of the Bistrica karst spring background (based on: Šikić et al., 1972; Petauer et al., 2002).

and flow unclean directly into the underground. Many of the pastoral houses also have their own manure heaps, which are not regulated according to the water-protection standards. The upper limit of cattle number on each mountain meadow is traditionally limited and consequently cattle density does not pose a threat to the quality of groundwater. Diesel generating set that is driving the ski lifts presents a potential threat to the groundwater. Since the natural snowfall is commonly insufficient and artificial snow is not created, the ski lifts mostly stand idle. For that reason ski slopes and cableway are not identified as potential threats to the quality of the groundwater.

There are several illegal waste-disposal dumps. On Velika planina only, there were 40 garbage dumps registered in 2002. Their common volume amounted $250 \mathrm{~m}^{3}$ of waste material. The dumps are most frequent in the vicinity of tourist settlements, where the frequency of visitors is the highest and where holiday huts are owned by different public and private companies. Northward and southward of Šimnovec private holiday huts prevail, therefore also illegal dumps are less frequent. Least of all dumps are present in the pastoral settlement. On the dumps domestic, building and furniture waste material prevail, while there is no dangerous waste material (Palčič, 2002).

Wastewaters represent the most dangerous hazard to groundwater contamination and the first signs of contamination have already been recorded in the respective karst springs. Some of them are also captured for water supply. Chemical and bacteriological analyses of water (Novak, 1994/1995) have shown, that the capturings are threatened due to the different human activities taking place on the plateau. However, the water is still suitable for drinking. Concentrations of chemical pollution did not exceed values stipulated by law. Also bacteriological analyses of water have been acceptable. Chemical and bacteriological analyses of spring waters showed increased consumption of $\mathrm{KMnO}_{4}$ in two springs, that is an index of organic pollution. Higher concentrations of $\mathrm{PO}_{4}$ and $\mathrm{NO}_{3}$ in a few springs indicate pollution from domestic sewages or products of decomposition. Increase of tourist capacities could mean strong enlargement of the wastewaters amount.

\section{The Snežnik plateau}

\subsection{Natural characteristics}

The Snežnik plateau extends over $293 \mathrm{~km}^{2}$. The plateau is a deeply karstified area, built mostly of Cretaceous and Jurassic limestones, dolomites and dolomite-limestone breccias of well and medium permeability (Šikić et al., 1972; Šikić and Pleničar, 1975). Tectonically, the Snežnik plateau is part of the Snežnik thrust sheet and belongs to the northwestern Dinarids (Placer, 1981). The plateau is situated at the southeastern part of the belt of High Dinaric Karst, where uninterrupted landscape of the High Karst in Slovenia is continuing beyond the Slovene-Croatian border in the area of Gorski Kotar mountains. In the west the Snežnik plateau borders to the tertiary impermeable flysch (shales, marlstone, sandstone, calcarenites, breccias and conglomerates) of the Reka valley and Brkini hills, which forces the karst water to outflow in several springs (see Fig. 5). The limitation of the plateau to the south and north is not evident, while it is well observable at the west and also at the east margin, where the plateau is bordering to the karst poljes of Notranjska region. The central part of the plateau lies at an average elevation of 1000 to $1400 \mathrm{~m}$; the highest peak is Snežnik $(1796 \mathrm{~m})$. Due to an orographic barrier, precipitation in the central parts of the Snežnik plateau is rather abundant and the peaks of the mountains reach approximately $3000 \mathrm{~mm}$ per year.

The plateau karst surface is characterized by conicalshaped hills, deep dolines of various shapes, size and morphogenesis, deep shafts and typical glacio-karstic depressions filled with glacial debris from the last Glacial when the mountain of Snežnik was ice-capped and some small slope glaciers were active (Šifrer, 1959). On some spots small moraines can be found as well. There are around 318 registered karst caves in this area, among them shafts prevail ${ }^{5}$. Average depth of the caves is $28 \mathrm{~m}$, but only 12 of them are deeper than $100 \mathrm{~m}$. The longest and the deepest cave is Brezno Bogumila Brinška that is $585 \mathrm{~m}$ long and $506 \mathrm{~m}$ deep. Average length of the caves is $39 \mathrm{~m}$. Intensive karstification and poor soil cover on the limestones enable the precipitation water to drain underground quickly by concentrated recharge via dolines, shafts and karrenfields. Consequently, the protective cover of the overlaying layers is completely bypassed and such locations are naturally more sensitive and particularly exposed to pollution.

In addition to running towards the Bistrica karst springs (mean annual discharge $1.85 \mathrm{~m}^{3} / \mathrm{s}$ ), the autochthonous precipitation water which percolates into the deep karst aquifer

\footnotetext{
${ }^{5}$ Cadastre of caves, Speleological association of Slovenia and Karst research institute SRC SASA, Ljubljana, 2003.
} 
runs towards other karst springs in its margin. The underground watershed between several karst springs and also between the Adriatic and Black Sea basins is found in the area of the plateau, but they are not yet defined. Although the local erosion base of the Reka valley, which drains karst springs in the western margin of the plateau, is among the lowest $(400 \mathrm{~m})$, the majority of abundant precipitation runs towards the catchment area of the rivers Ljubljanica $(555 \mathrm{~m})$ and Riječina (350 m) in Croatia.

The next section deals with the description of hazards in the background of the Bistrica karst springs (major outflow on the west margin of the plateau), which, accordingly to Petauer et al. (2002) stretches over $90 \mathrm{~km}^{2}$, although the extent of the suggested water-protection zones is slightly overestimated, but it is rational in terms of water protection. Since one of the springs (Bistrica karst spring) is captured for the water supply of a nearby community, its catchment area has therefore been more investigated than other parts of the Snežnik plateau. Nevertheless, it is the authors' opinion that the more serious potential polluters of groundwater on the Snežnik plateau are mostly found in the catchment area of the abovementioned springs, and rarely elsewhere.

\subsection{Description of hazards}

Due to its elevations, geological, geomorphological and consequently climate conditions the Snežnik plateau is most inconvenient for agriculture and for this reason uninhabited. Thus it is relatively favourable for water protection. The plateau is densely wooded, but on lower elevations some pastures are still in use. The Snežnik plateau is an excellent example showing that even in uninhabited karst areas some serious potential hazards can be found, which constitute a threat to the quality of groundwater. The respective captured Bistrica karst spring is threatened by sports (trapshooting ground), construction (two quarries), tourist (small tourist resort), forestry and farming activities taking place in its catchment area, as well as traffic related to them. Water quality analyses recorded a slight increase in the values of lead (trapshooting ground), however the concentrations are still within the maximum permissible values for drinking water.

In the area of former military shooting ground situated in the vicinity of the Bistrica karst springs $(700 \mathrm{~m}$ to the northeast of the spring), since later 1980s, a trapshooting ground has been operating. Although trapshooting is a sport, such activity is the most serious hazard for groundwater and should not be placed in the catchment areas of drinkable water resources. The active shooting range is situated in a shallow doline, where, in comparison with the surroundings, the soil layer is thicker. Estimates show that the concentration of lead (the element with which cartridges used for trapshooting are filled) in the soil is rather high. According to the Decree on the input of dangerous substances and plant nutritients into the soil of 1996, maximum annual permissible quantities of lead entered into the soil is $2.5 \mathrm{~kg} / \mathrm{ha}$. Considering to the size of the shooting ground and the weight of a single cartridge ( $24 \mathrm{~g}$ ) as few as 150 bullets fired would be enough to exceed the aforementioned annual maximum permissible value on the active shooting ground. However, in the case of the abovementioned trapshooting ground this number is far exceeded each year. While percolating through the thin layer of soil, the infiltrating precipitation water becomes, to some extent, contaminated with lead, which is a result of weak acids. The earlier physical-chemical examinations of the spring water showed a concentration of lead, which was still within the maximum permissible values. According to analyses carried out later (July 2002), however, a slight increase in the values of lead is recorded $(4 \mu \mathrm{g} / \mathrm{l})$ and the trend is not encouraging (Poročila o preskusu pitne vode za zajetje Bistrica, 1999-2003). ${ }^{6}$. The maximum permissible concentration of lead in the drinking water is $10 \mu \mathrm{g} / \mathrm{l}$. It is impossible to determine the total quantity of lead in the soil cover, in addition to the fact that there are no data available on the amounts of lead and other toxic substances which already entered the karst during the earlier period while the military shooting ground was still active. No analyses of the soil have been carried out so far in order to study the behaviour of lead as a specific contaminant and to examine the intrinsic processes of the soil for its possible physical attenuation. The closure of the trapshooting ground and the remediation of the contaminated surface and the soil cover are necessary to ensure quality drinking water in the future.

In the catchment area of the Bistrica karst spring there are two quarries, but one of them is no longer operational for active mining. Although the lower quarry, located only $200 \mathrm{~m}$ to the north from the capture, is no longer functioning, it is still used for milling the limestone carried from the upper quarry. Inappropriate oil storage and several other unsuitable activities that increase the potential risk of pollution can be found in the working area of the lower quarry. Until recently the quarry was for a short period also used as a waste dump for construction material. Among this material also some hazardous waste could be found, such as car accumulators, used lacquer and colour cans, etc. Chemical analyses of the water captured from the spring show sporadically increased values of mineral oils, which are likely to result from inappropriate limestone exploitation in the past, which did not meet water protection standards. The remediation of the lower quarry is therefore essential for a long-term protection of drinking water. The upper quarry, situated about $5 \mathrm{~km}$ eastward from the spring, is still operating. Its average annual production of limestone is around $50-100000 \mathrm{~m}^{3}$. For water protection the activities carried out in the abovementioned quarry should also comply with water protection standards.

The Snežnik karst plateau has no permanent inhabitants, however in the part of the plateau which coincides with the background of the Bistrica springs, there are several mountaineering huts and weekend houses and also the tourist set-

\footnotetext{
${ }^{6}$ Water quality monitoring reports of the Bistrica spring capture, Health protection institute of the Republic of Slovenia, Koper, 1999-2003.
} 
tlement Sviščaki. Sviščaki is a tourist resort with a small restaurant and some 90 weekend houses. Although it is situated in the central part of the plateau, it should be considered as a potential source of pollution because the eastern boundary of the catchment area has not yet been precisely delineated. In addition, the inadequate sewerage infrastructure, which does not meet water protection standards, represents a possible threat to underground water quality. Wastewaters from the restaurant and weekend houses are drawn off to cesspits, but the quality of their construction is doubtful. Wastewaters probably infiltrate into the subsurface of karst aquifer, which is a possible threat for drinking water. The quantity of wastewater is small.

Apart from pollution from construction, sports, tourism and forestry activities the Bistrica karst spring is also endangered by traffic. In the Snežnik plateau there are many macadam roads used mainly for forestry activities and the local road connecting Ilirska Bistrica with Sviščaki. The road runs right above the capture and is not built according to water protection standards, which means that the meteor waters from the road are freely entering the subsurface, without previous treatment. Since the traffic density is very low, the influence of traffic on the quality of the spring water is negligible, but the potential risk of the contamination in the case of an accident is anyway high. Since the local road is drawn off in the vicinity of the capture, in the case of an accident the contaminants would reach the spring very quickly, making efficient emergency action impossible.

The influence from the forestry and farming activities to the quality of karst water is negligible. In the Snežnik plateau the sustainable forest management has a tradition of several hundred years. Possible threat to the quality of groundwater is the traffic related to the forestry activity. Some parts of the Snežnik plateau in the background of the Bistrica springs are used for sheep pasturing, but the sheep density is low and does not pose a threat to the quality of the karst groundwater.

\section{Discussion and conclusion}

Karst aquifers in Slovenia, specially High Dinaric Karst and Alpine Karst are, due to scarce population, less intensive agricultural activities, etc., more convenient for water protection as compared with the intergranular aquifers (dense population, intensive industry, traffic and agriculture activity, immoderate groundwater exploitation, etc.). Slovenia is known for abundant resources of relatively high quality drinkable water, which is not exploited as a whole. Therefore karst groundwater is often considered as a self-evident and plentiful natural resource despite the fact that it is extremely vulnerable to pollution. Evident differences in types of potential and actual hazards and their spatial distribution between inhabited and uninhabited karst regions are explained in the text, showing that the inhabited Kras plateau is threatened by more diverse types of hazards, coming from different human activities. Contrary to the common opinion, the present article also confirms that some serious potential hazards to the quality of karst groundwater can be found even in uninhabited areas, like in the case of the Velika planina and the Snežnik karst plateau.

As karst aquifers are very dynamic systems and monitoring points of groundwater pollution scarce, the detection of actual hazards is very difficult. Possible are analyses performed at springs and wells at different depths. Although extensive exploitation of karst aquifers has often been avoided until now, some signs of contamination have already been recorded in several karst springs in Slovenia.

In all three selected karst aquifers point and line hazards prevail coming from either sports, tourist, construction, forestry, farming, industrial and other activities as well as from the traffic related to them. Agriculture and farming are not intensive on the selected plateaus, therefore they do not significantly affect the quality of the karst groundwater, except in the case of viticulture on the Kras plateau. The influence of the extensive usage of fertilizers and protective means for viticulture on the quality of karst groundwater has not been researched so far. Roads, highways and railways that are crossing the recharge areas are serious potential sources of accidental pollution. Landfills in karst terrains may influence the quality of groundwater by bacterial and chemical load as well. Sources of pollution are also industrial effluents on the Kras plateau, specially in the cases, where wastewater collection and drainage systems are not built. An example is the ham-curing plant.

Since the protection regimes of drinking water sources are often established inappropriately and control over the implementation of protective measures is inefficient, obvious offenders of water protection measures are usually not prosecuted because of inefficient inspection. Mapping of the potential and actual sources of pollution is a valuable practical tool for further land-use planning and groundwater protection but many of them can not be yet confirmed.

Slovenia has a unique opportunity to preserve qualitative quantities of karst groundwater for exploitation in the future. In order to ensure appropriate quality of this unique natural resource it is necessary to establish adequate protection, which consists of the determination of different water protection zones with respective regimes. It is above all essential to educate the population of the significance of sustainable water management in karst regions. However, good co-operation between scientists, planners and decision makers is needed to avoid land use conflicts and to work together in a framework of the integral karst protection.

Edited by: M. Parise

Reviewed by: two referees 


\section{References}

Buser, S., Grad, K., and Pleničar, M.: Osnovna geološka karta SFRJ 1:100 000, list Postojna, Zvezni geološki zavod Beograd, Beograd, 1963.

Buser, S.: Osnovna geološka karta SFRJ 1:100 000, list Gorica, Zvezni geološki zavod Beograd, Beograd, 1964.

Buser, S.: Osnovna geološka karta Jugoslavije, Tolmač za list Gorica, Zvezni geološki zavod Beograd, Beograd, 50, 1973.

Cività, M., Cucchi, F., Eusebio, A., Garavoglia, S., Maranzana, F., and Vigna, B.: The Timavo Hydrogeologic system: An important reservoir of supplementary water resources to be reclaimed and protected, Acta Carsologica, Ljubljana, 24, 169—186, 1995.

Decree on the emission of substances in the discharge of landfill effluent: Official Gazette of the Republic of Slovenia, 7, 944, 2000.

Decree on the emission of substances in wastewater discharged from urban waste water treatment plants: Official Gazette of the Republic of Slovenia, 35, 2967-2968, 1996.

Decree on the input of dangerous substances and plant nutritients into the soil, Official Gazette of the Republic of Slovenia, 68, 5769-5737, 1996.

Gemiti, F.: La portata del Timavo alle risorgive di S. Giovanni di Duino, Annali Gruppo Grotte Ass. XXX Ott., 7, Trieste, 23-41, 1984.

Habič, P.: Water table in Slovene karst of Notranjsko and Primorsko, Acta Carsologica, 13, Ljubljana, 37-78, 1984.

Jurkovšek, B., Toman, M., Ogorelec, B., Šribar, L., Drobne, K., Poljak, M., and Šribar, L.:Geological map of the southern part of the Trieste-Komen Plateau 1:50 000, Cretaceous and Paleogene carbonate rocks, Inštitut za geologijo, geotehniko in geofiziko, Ljubljana, 143, 1996.

Kogovšek, J.: How rubbish dumps have imperilled the quality of karst water, Kako smetišča ogrožajo kakovost kraške vode, Annales, 9, Koper, 111-114, 1996.

Kopač, M.: Velika planina. Valorizacija krajinskega območja za potrebe razvoja, Katedra za krajinsko arhitekturo Biotehniške fakultete, Ljubljana, 34, 1991.

Kranjc, A., Culiberg, M., Likar, V., and Žalik Huzjan, M. et al. (eds.): Kras - pokrajina, življenje, ljudje, Založba ZRC (ZRC SAZU), Ljubljana, 321, 1999.

Krivic, P.: Interprétation des essais par pompage réalisés dans un aquifère karstique, Geologija, 26, Ljubljana, 149-186, 1983.
Krivic, P., Bricelj, M., and Zupan, M.: Underground water connections in čičarije region and in middle Istra, Acta Carsologica, 18, Ljubljana, 265-295, 1989.

Novak, D.: Underground waters in Kamnik and Savinja Alps, Geologija, 37, 38, Ljubljana 415-435, 1994/1995.

Palčič, M.: Pokrajinski vidiki sanacije odlagališč odpadkov na Veliki planini, Diplomsko delo, Oddelek za geografijo Filozofske fakultete Univerze v Ljubljani, 37, 2002.

Petauer, D., Juren, A., Štucin, P., and Ilovar, S.: Strokovne podlage za zaščito vodnih virov občine Ilirska Bistrica, GEOOKO \& GeoSi, Ljubljana, 66, 2002.

Placer, L.: Geologic structure of southwestern Slovenia, Geologija, 24/1, Ljubljana, 27-60, 1981.

Pleničar, M., Polšak, A., and Šikić, D.: Osnovna geološka karta SFRJ 1:100000, list Trst, Zvezni geološki zavod Beograd, Beograd, 1965.

Premru, U.: Osnovna geološka karta Jugoslavije. Tolmač za list Ljubljana, Zvezni geološki zavod Beograd, Beograd, 75, 1982.

Prestor, J.: Problematika določanja varstvenih pasov in razporeditve ukrepov za zaščito vodnih virov, in: Zbornik seminarjev Varstvo in kvaliteta pitne vode, Inštitut za sanitarno inženirstvo, 69-77, 2002.

Rejec-Brancelj, I.: .: Agricultural environmental pollution in Slovenia: landscape aspects of agricultural pollution from the dispersed sources, Inštitut za geografijo, Ljubljana, 104, 2001.

Šifrer, M.: Obseg pleistocenske poledenitve na Notranjskem Snežniku, Geografski zbornik, 5, Ljubljana 27-83, 1959.

Šikić, D., Pleničar, M., and Šparica, M.: Osnovna geološka karta SFRJ 1:100 000, list Ilirska Bistrica, Zvezni geološki zavod Beograd, Beograd, 1972.

Šikić, D. and Pleničar, M.: Osnovna geološka karta Jugoslavije. Tolmač za list Ilirska Bistrica, Zvezni geološki zavod Beograd, Beograd, 51, 1975.

Timeus, G.: Nei misteri delmondo sotterraneo, Risultati delle ricerche idrologiche sul Timavo 1895-1914, 1918-1927, Alpi Giulie, 19, Trieste, 1-39, 1928.

Waters Act: Official Gazette of the Republic of Slovenia, 38, 2308 2320, 1981.

Waters Act: Official Gazette of the Republic of Slovenia, 67, 76487680, 2002.

Zwahlen, F.: Vulnerability and Risk Mapping for the Protection of Carbonate (Karstic) Aquifers, Final report COST action 620, European Commission, Directorate-General for Research, Brüssel, Luxemburg, 297, 2004. 